\title{
The effect of soil mulching with straw on the yield and selected components of nutritive value in broccoli and tomatoes
}

Edyta Kosterna

Department of Vegetables Siedlce University of Natural Sciences and Humanities B. Prusa 14, 08-110 Siedlce, Poland

\begin{abstract}
By maintaining proper moisture and reducing daily temperature fluctuations, mulching improves soil conditions for plant growth and development, resulting in a positive effect on the vegetable yield. The chemical composition of vegetables is genetically determined as well as being modified by factors affecting the plant during growth, and particularly climatic conditions and agro-technology practices. The effects of soil mulching with rye, corn, rape and buckwheat straw at a dose of 10 and $20 \mathrm{t} \mathrm{ha}^{-1}$ on the yield and changes of selected components of nutritive value in 'Milady' $F_{1}$ broccoli and 'Polfast' $F_{1}$ tomato were investigated. The effect of straw was compared to a control plot without mulch. The yield of the vegetables and their chemical composition depended to a higher degree on weather conditions in the years of study. 2010 was the most favourable for broccoli yielding and 2011 for tomato. More nutrients components in heads and fruits were found in 2011 and 2012, which were characterised by favourable rainfall distribution. All straws applied in the experiment, irrespective of dosage, caused an increase in broccoli yield. However, soil mulching with straw at a dose of $10 \mathrm{t} \mathrm{ha}^{-1}$ was better for tomato yielding. Soil mulching with rye, corn and buckwheat straw increased the share of marketable yield in the total yield of broccoli and rye straw as well as the share of marketable yield of tomato. Mulching with rape and buckwheat straw decreased dry matter content in the edible parts of the vegetables. Mulch with rye straw contributed to a decreased content of ascorbic acid in heads and fruits and also caused a slight reduction in tomato flesh acidity. However, soil mulching with corn and rape straw caused an increase in total sugars and monosaccharide content in broccoli and tomato.
\end{abstract}

Key words: ascorbic acid, dry matter, flesh acidity, straw, sugars, vegetables, yield

\section{INTRODUCTION}

All treatments that protect the soil from degradation and use plant protection methods other than chemicals are of great importance in organic farming (Adamczewska-Sowińska and Kołota 2008). Among others, options for such treatment include organic mulches, which limit the growth of weeds, protect the soil from drying out and reduce the leaching of nutrients, resulting in a positive effect on the cultivated plant yield and improving its quality (Schonbeck and Evalylo 1998, Thakur et al. 2000, Gajc-Wolska et al. 2005, Ghosh et al. 2006, Rahman et al. 2006, Dahiya et al. 2007, Saeed and Ahmad 2009). According to Björkman and Pearson (1998) and Birch et al. (2000) plant 
growth conditions are the main determinant of the quality of their yield.

The chemical composition of vegetables is genetically determined as well as being modified by factors affecting the plant during growth, and particularly climatic conditions and agrotechnology practices (Steinmetz and Potter 1996, Lee and Kadar 2000).

Changes in yields and nutrient content due to soil mulching were found by Samaila et al. (2011a, b) in tomato fruits, by Najafabadi et al. (2012) in garlic, by Olfati et al. (2008) in carrot roots and by Sekhon at al. (2008) and Gajc-Wolska et al. (2005) in sweet pepper.

The current research shows that the most common organic mulch is used rye straw. There is a scarcity of reports regarding the possibility of applying straw of different kinds of species.

This study aimed to determine the effect of mulch using different kinds of straw on the yields and changes in selected components of nutritive value of broccoli heads and tomato fruits.

\section{MATERIAL AND METHODS}

The experiment was carried out between 2010 and 2012 at the Experimental Farm in Zawady, which is located in central-eastern Poland $\left(52^{\circ} 03^{\prime} \mathrm{N}\right.$, $\left.22^{\circ} 33^{\prime} \mathrm{E}\right), 115 \mathrm{~km}$ east of Warsaw. According to the international system of FAO classification, the soil was classified as a Luvisol (LV) (WRB FAO 1998). The soil organic matter content averaged $1.5 \%$ and its humus horizon reached a depth of 30 $40 \mathrm{~cm}$, the value of $\mathrm{pH}$ determined in $\mathrm{H}_{2} \mathrm{O}$ was 5.4 . The total contents of macroelements in $\mathrm{mg} \mathrm{dm}^{-3}$ air dried matter amounted to 34 for phosphorus, 83 for potassium, 36 for magnesium, 14 for $\mathrm{N}_{-} \mathrm{NO}_{3}, \mathrm{~N}-7$ for $\mathrm{NH}_{4}$ and 260 for calcium. The content of plantavailable nutrients was lower than that specified by Sady (2000).

The experiment was established as a splitblock design with three replicates. The effect of soil mulching with rye, corn, rape and buckwheat straw at a dose of 10 and $20 \mathrm{tha}^{-1}$ on the yield and changes of selected components of nutritive value in 'Milady' $F_{1}$ broccoli and 'Polfast' $F_{1}$ tomato was investigated. The effect of the straw was compared to a control plot without mulch.

The forecrop for the vegetables was triticale. In the autumn preceding broccoli and tomato cultivation, ploughing was performed. At the same time, farmyard manure was incorporated at a rate of $30 \mathrm{t} \mathrm{ha}^{-1}$. In the spring, two weeks before the seedlings were planted, disc harrowing was applied to loosen the upper soil layer and prepare it for planting. After that, mineral fertilisers were applied in the amount of supplementary content to the optimal level for broccoli: $110 \mathrm{~kg} \mathrm{~N}, 98 \mathrm{~kg} \mathrm{P}_{2} \mathrm{O}_{5}$, $220 \mathrm{~kg} \mathrm{~K} \mathrm{O}_{2}$ per 1 ha and for tomato: $85 \mathrm{~kg} \mathrm{~N}, 104$ $\mathrm{P}_{2} \mathrm{O}_{5}, 234 \mathrm{~K}_{2} \mathrm{O}$ per 1 ha. Mineral fertilisers were applied in the form of ammonium nitrate, triple superphosphate and $60 \%$ potassium salt.

Directly before seedling planting, the particular kind of straw was applied in the appropriate dose. The thickness of the mulch layer depended on the kind of straw. In the case of rye and rape straw, application at a dose of $10 \mathrm{t} \mathrm{ha}^{-1}$ mulch thickness amounted to $7-8 \mathrm{~cm}$ on average; in the case of corn straw, the mulch layer amounted to about $5 \mathrm{~cm}$; however, for buckwheat straw the average was 8-10 $\mathrm{cm}$. At a dose of $20 \mathrm{tha}^{-1}$ the mulch layer was two times higher.

Broccoli seedlings were grown in a nonheated greenhouse. Seeds $(10 \mathrm{~g})$ were sown in the successive study years on the $19^{\text {th }}, 18^{\text {th }}$ and $20^{\text {th }}$ of March in multi-trays (54 holes). The seedlings were produced using peat substrate. Before planting, seedlings were moved outdoors. Plants were planted on the $19^{\text {th }}, 18^{\text {th }}$ and $23^{\text {rd }}$ of April, at a spacing of 50 $\times 50 \mathrm{~cm}$. The area of one plot for harvest was $12 \mathrm{~m}^{2}$. 48 plants were planted on each plot.

Tomato seedlings were grown in a heated greenhouse. The seeds were sown at a rate of $10 \mathrm{~g}$ to seedling containers with peat substrate on 18 March in 2010 and 2011 and 28 March in 2012. After cotyledon formed and at the beginning of first leaf emergence, the seedlings were bedded into pots with a diameter of $8-10 \mathrm{~cm}$ (1 April in 2010 and 2011 and 11 April in 2012). Prior to transplanting the seedlings were hardened off and then moved permanently outdoors. Plants were planted in the successive study years on 20,16 and 14 May, at a spacing of $60 \times 40 \mathrm{~cm}$. The area of one plot for harvest was $6 \mathrm{~m}^{2} .18$ plants were planted on each plot.

Three weeks after the broccoli and tomato seedlings were planted, $50 \mathrm{~kg} \mathrm{~N} \mathrm{ha-1}$ in the form of ammonium nitrate was applied (top dressing). During the growing season, systematic tomato plant protection against fungal diseases was carried out. At 10-day intervals, the following plant protection sprays were applied: Infinito $687.5 \mathrm{SC}$, Amistar 250 SC and Ridomil Gold ${ }^{\circledR}$ MZ Pepite 67.8 WG.

Broccoli was harvested by hand on 30 June in 2010 and 28 June in 2011 and 2012. Tomato fruit harvesting was performed several times as the fruit ripened. The beginning of harvest occurred in the 
last 10 days of July and at the end in the first 10 days of September. During the harvest the yield of broccoli and tomato was determined. From each plot a head sample (10 heads) was taken to perform chemical analyses. Tomato in the quantity of 20 fruits from each plot intended for analysis was taken during full fruiting (mid-August). The following was determined in the heads and fruits:

- dry mass - by drying to a constant weight at $105^{\circ} \mathrm{C}$ (Polish Standard PN-90/A-75101/03),

- total sugars and monosaccharides - using the Luff-Schoorl method (Polish Standard PN-90/A-75101/07),

- L-ascorbic acid - using the Tillman method modified by Pijanowski (Polish Standard PN-A-04019).

The flesh acidity of tomato ( $\mathrm{g} 100 \mathrm{~g}^{-1}$ counted on lemon acid) was also estimated.

The results of the experiment were statistically analysed by means of the analysis of variance following the mathematical model for the splitblock design. Significance of differences was determined by the Tukey test at the significance level of $\mathrm{p}=0.05$.

Weather conditions in the study years were varied (Tab. 1). 2010 and 2012 were more favourable for broccoli growth. They were characterised by higher air temperature in May (the period in which plants are growing and developing) and higher rainfall during the growing period compared with 2011. 2011 was characterised by quite high mean air temperatures but very irregular rainfall distribution. Compared with the other study years, not much rain fell in May and June, in the period of plant growth and development and head formation.

The tomato is a plant that requires high temperatures and moderate rainfall during the growing season. 2011 and 2012 had more favourable conditions for tomato growth. These years were characterised by similar temperatures during the growing period, especially in 2011. In addition, obtaining good quality of fruit requires relatively low rainfall in August and September (the period in which fruits are growing and maturing). The least favourable conditions for tomato growth and development were in 2010, which was characterised by quite high mean air temperatures but also higher rainfall compared to the other study years, favouring fungal diseases.

During the plant growing period, measurement of the soil temperature was performed at a depth of $10 \mathrm{~cm}$ in all objects, at 8:00 a.m. and 2:00 p.m. (Figs 1 and 2). The soil temperature in the plots without straw was higher than in plots with straw. The decrease in soil temperature as a result of mulching amounted to $1.5^{\circ} \mathrm{C}$ at $8: 00$ a.m. and $3.8^{\circ} \mathrm{C}$ at $2: 00$ p.m when straw at a dose of $10 \mathrm{t} \mathrm{ha}^{-1}$ was applied, and $1.7^{\circ} \mathrm{C}$ and $4.6^{\circ} \mathrm{C}$, respectively, when straw at a dose of $20 \mathrm{t} \mathrm{ha}^{-1}$ was applied. The lowest fall in temperature compared to the control plot was observed in plots mulched with buckwheat straw. The reductions in soil temperature as a result of buckwheat straw application at a dose of $10 \mathrm{t} \mathrm{ha}^{-1}$ amounted to $1.1^{\circ} \mathrm{C}$ at $8: 00$ a.m. and $3.2^{\circ} \mathrm{C}$ at $2: 00$ p.m, and 1.5 and $4.4^{\circ} \mathrm{C}$, respectively, in plots with straw at a dose of $20 \mathrm{t} \mathrm{ha}^{-1}$. The cause of smaller differences in soil temperature between the control object and objects with buckwheat straw mulch may be the darker colour of the straw.

\section{RESULTS AND DISCUSSION}

The total yield of broccoli amounted to 17.51 $\mathrm{t} \mathrm{ha}^{-1}$ and $54.83 \mathrm{t} \mathrm{ha}^{-1}$ for tomato (Tab. 2). The yield level depended to a higher degree on the weather conditions. The highest total yield of broccoli was obtained in 2010, the most favourable for its

Table 1. Mean air temperature and precipitation sum in the vegetation period of broccoli and tomato

\begin{tabular}{lrrrrrrr}
\hline \multicolumn{9}{c}{ Temperature $\left({ }^{\circ} \mathrm{C}\right)$} \\
\hline Years & April & May & June & July & August & September & Mean \\
\hline 2010 & 8.9 & 14.0 & 17.4 & 21.6 & 19.8 & 11.8 & 15.6 \\
2011 & 10.1 & 13.4 & 18.1 & 18.3 & 18.0 & 14.4 & 15.4 \\
2012 & 8.9 & 14.6 & 16.3 & 20.7 & 18.0 & 14.1 & 15.4 \\
\hline Mean 1951-1990 & 7.2 & 13.2 & 16.2 & 17.6 & 16.9 & 12.7 & 14.0 \\
\hline & & & Rainfall $(\mathrm{mm})$ & & & & \\
\hline 2010 & 10.7 & 93.2 & 62.6 & 77.0 & 106.3 & 109.9 & 459.7 \\
2011 & 31.0 & 36.1 & 39.1 & 120.2 & 18.6 & 12.0 & 257.0 \\
2012 & 29.9 & 53.4 & 76.2 & 43.0 & 51.0 & 11.4 & 264.9 \\
\hline Mean 1951-1990 & 29.4 & 54.3 & 69.3 & 70.6 & 59.8 & 48.2 & 331.6 \\
\hline
\end{tabular}




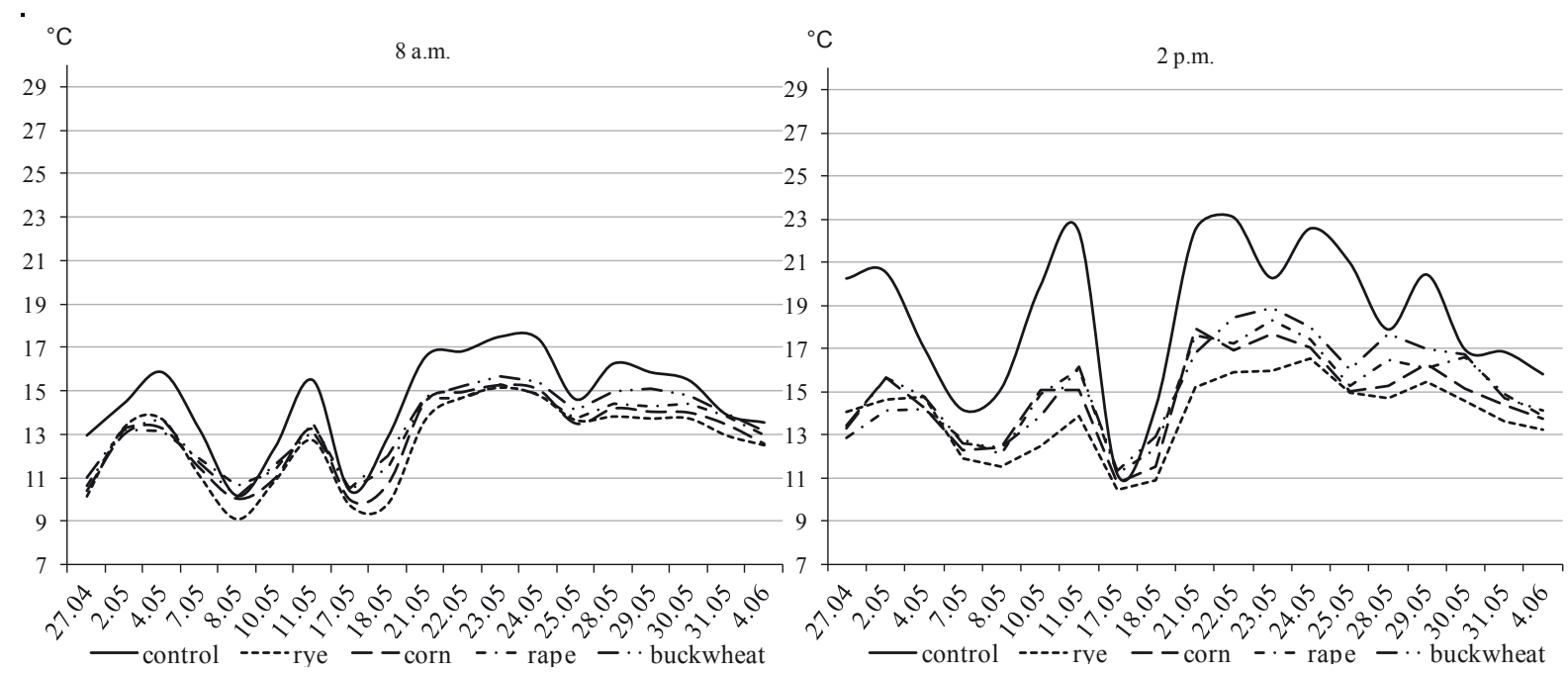

Figure 1. Soil temperature $\left({ }^{\circ} \mathrm{C}\right)$ at a depth of $10 \mathrm{~cm}$ on different kinds of straw at a dose of $10 \mathrm{t} \mathrm{ha}^{-1}$ measured at 8 a.m. and 2:00 p.m.
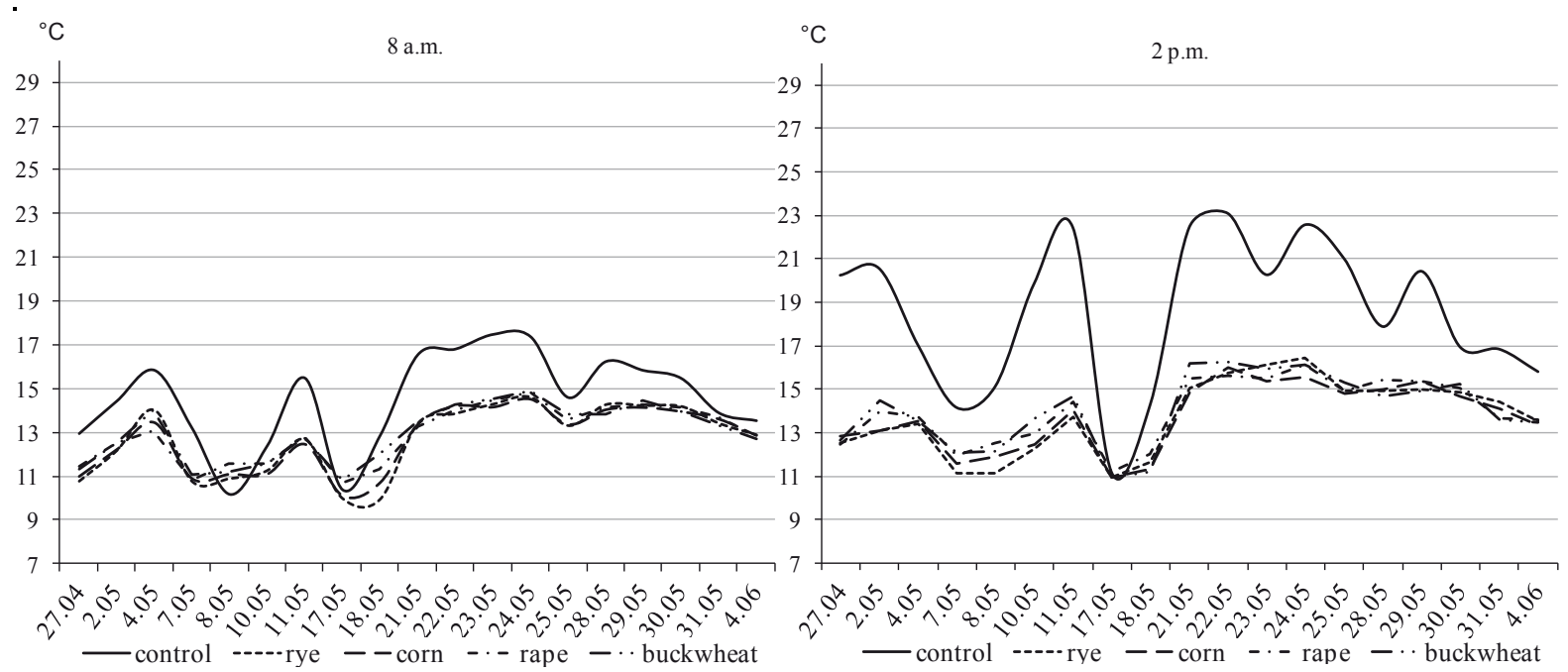

Figure 2. Soil temperature $\left({ }^{\circ} \mathrm{C}\right)$ at a depth of $10 \mathrm{~cm}$ on the different kind of straw at a dose of $20 \mathrm{t}$ ha- 1 measured at 8:00 a.m. and 2:00 p.m.

cultivation. In the least favourable year, 2011, the total yield was lower on average by $5.70 \mathrm{t} \mathrm{ha}^{-1}$. In turn, for tomato yield the most favourable was 2011, which was characterised by moderate rainfall. In that year, the yield of fruits was higher on average by $9.75 \mathrm{tha}^{-1}$ compared to 2010 and by $13.24 \mathrm{t} \mathrm{ha}^{-1}$ compared to 2012. A high influence of weather conditions on broccoli yield was also reported by Kałużewicz et al. (2010) and Karistsapol et al. (2013) and on tomato yield by Borowy (2012).

The study results showed a significant influence of the interaction between the kind and dose of straw applied to soil mulching on the yield level of the investigated species (Tab. 2). It was found that all kinds of straw investigated in the experiment irrespective of dose contributed to a significant increase in the total yield of broccoli. Significantly, the lowest yields were obtained from the plots without straw. Soil mulching with rape and buckwheat straw at a dose of $10 \mathrm{t} \mathrm{ha}^{-1}$ contributed to a significant increase in the broccoli yield compared to plots mulched with straw at a dose of $20 \mathrm{t} \mathrm{ha}^{-1}$. The increase in the yield amounted to 2.12 and 1.33 $\mathrm{t} \mathrm{ha}^{-1}$. In tomato cultivation, all straw applied at a dose of $10 \mathrm{tha}^{-1}$ caused an increase yield of fruits compared to those without straw. The application of rye, rape and buckwheat straw at a dose of 10 $\mathrm{t} \mathrm{ha}^{-1}$ caused an increased tomato yield compared to the dose of $20 \mathrm{t} \mathrm{ha}^{-1}$. In the studies by Samaila et al. (2011b), soil mulching significantly increased the total yield of tomato fruits compared with nonmulched plots. However, the researchers did not find 
Table 2. Total yield $\left(\mathrm{t} \mathrm{ha}^{-1}\right)$ of broccoli and tomato depending on kind of mulching straw in the years 2010-2012

\begin{tabular}{|c|c|c|c|c|c|c|c|}
\hline \multirow{2}{*}{ Species } & \multirow{2}{*}{\multicolumn{2}{|c|}{ Specification }} & \multicolumn{4}{|c|}{ Kind of straw } & \multirow{2}{*}{ Mean } \\
\hline & & & rye & corn & rape & buckwheat & \\
\hline \multirow{8}{*}{ Broccoli } & \multirow{3}{*}{ years } & 2010 & 19.89 & 22.46 & 18.31 & 19.50 & 20.04 \\
\hline & & 2011 & 14.98 & 14.60 & 13.38 & 14.40 & 14.34 \\
\hline & & 2012 & 17.46 & 19.22 & 17.91 & 17.95 & 18.13 \\
\hline & \multirow{3}{*}{$\begin{array}{c}\text { dose of straw } \\
\text { t ha }^{-1}\end{array}$} & No straw & 13.06 & 14.21 & 12.51 & 13.20 & 13.24 \\
\hline & & 10 & 20.16 & 20.85 & 19.61 & 19.99 & 20.15 \\
\hline & & 20 & 19.11 & 21.22 & 17.49 & 18.66 & 19.12 \\
\hline & \multicolumn{2}{|c|}{ mean } & 17.44 & 18.76 & 16.54 & 17.28 & 17.51 \\
\hline & \multicolumn{7}{|c|}{$\begin{array}{l}\text { LSD }_{0.05} \text { for: years }=3.83 ; \text { kind of straw }=\text { n.s.; dose of straw }=1.64 ; \text { years } \times \text { kind of straw }=\text { n.s.; kind of straw } \\
\times \text { dose of straw }=1.25\end{array}$} \\
\hline \multirow{8}{*}{ Tomato } & \multirow{3}{*}{ years } & 2010 & 56.53 & 48.95 & 45.46 & 60.03 & 52.74 \\
\hline & & 2011 & 66.40 & 68.28 & 55.33 & 59.93 & 62.49 \\
\hline & & 2012 & 37.77 & 55.78 & 50.93 & 52.53 & 49.25 \\
\hline & \multirow{3}{*}{$\begin{array}{c}\text { dose of straw } \\
\mathrm{t} \mathrm{ha}^{-1}\end{array}$} & No straw & 52.15 & 53.09 & 47.03 & 50.44 & 50.68 \\
\hline & & 10 & 58.48 & 59.20 & 54.75 & 66.55 & 59.74 \\
\hline & & 20 & 50.07 & 60.73 & 49.95 & 55.51 & 54.07 \\
\hline & \multicolumn{2}{|c|}{ mean } & 53.57 & 57.67 & 50.57 & 57.50 & 54.83 \\
\hline & $\begin{array}{l}\text { LSD }_{0.05} \text { for: yea } \\
\times \text { dose of straw }\end{array}$ & $\begin{array}{l}8.60 ; \mathrm{ki} \\
.59\end{array}$ & $\mathrm{w}=\mathrm{n}$ & stra & irs $\times$ & raw $=$ n.s.; & straw \\
\hline
\end{tabular}

significant differences in the yield level between particular kinds of mulch. Similarly Grassbaugh et al. (2004) and Saeed and Ahmad (2009) found that all organic mulches applied in their experiment caused an increased yield of tomato. In turn, in the study by Sinkevičienè et al. (2009), the yield level of vegetables significantly depended on the kind of mulch applied to soil mulching. The authors found that soil mulching with grass had the highest yielding effect. The yields of onion, red beet, cabbage and potato from plots with straw and peat

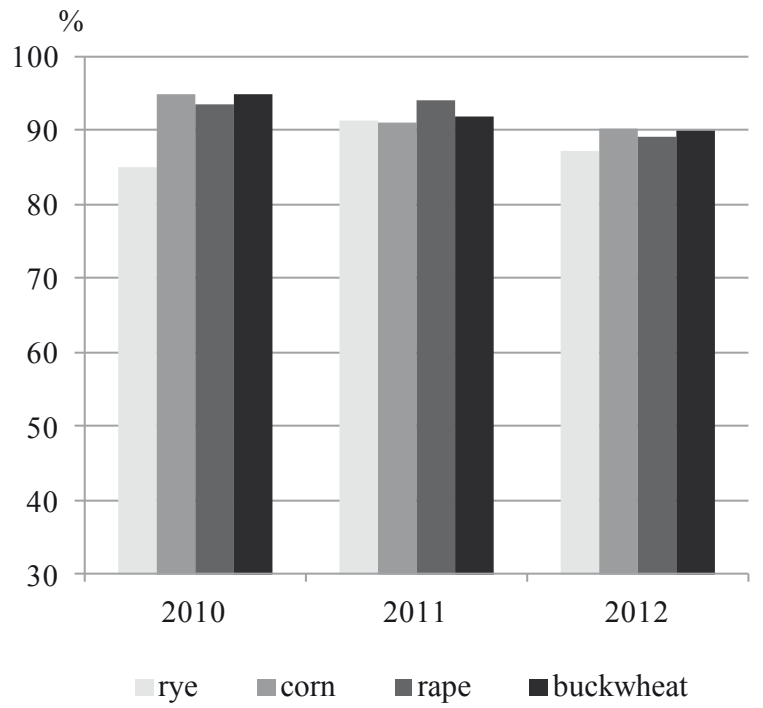

substrate mulch were similar; however, sawdust was less useful as a mulch.

Weather conditions in the study years influenced not only the total yield of broccoli and tomato but also the percentage share of marketable yield in the total yield (Figs 3 and 4). A higher share of marketable yield of broccoli was found in 2010 and 2011. The highest and lowest shares of marketable yield in the total yield of tomato were found in 2012 and 2010, respectively. In 2010, heavy rainfall coupled with high air temperatures contributed to

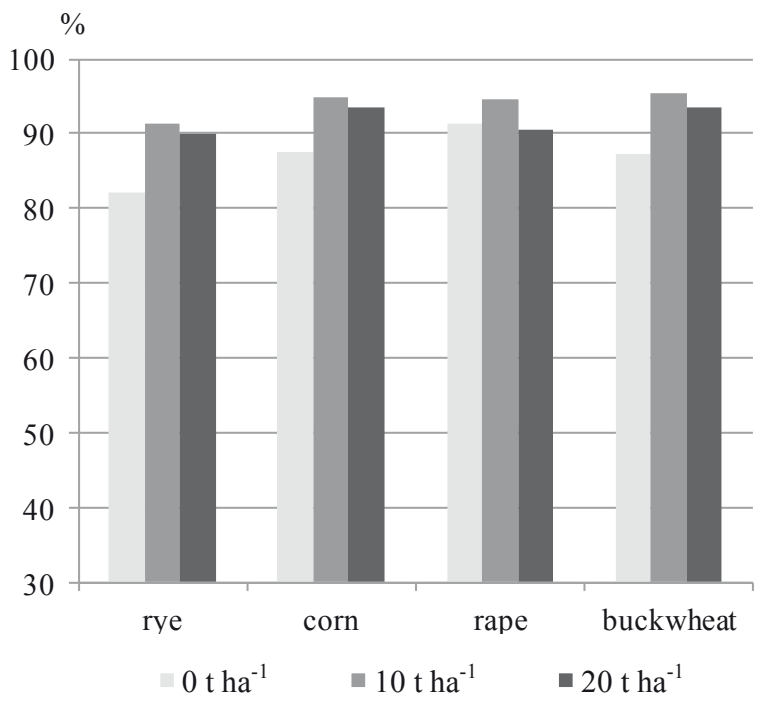

Figure 3. Share of marketable yield in the total yield of broccoli (\%) 

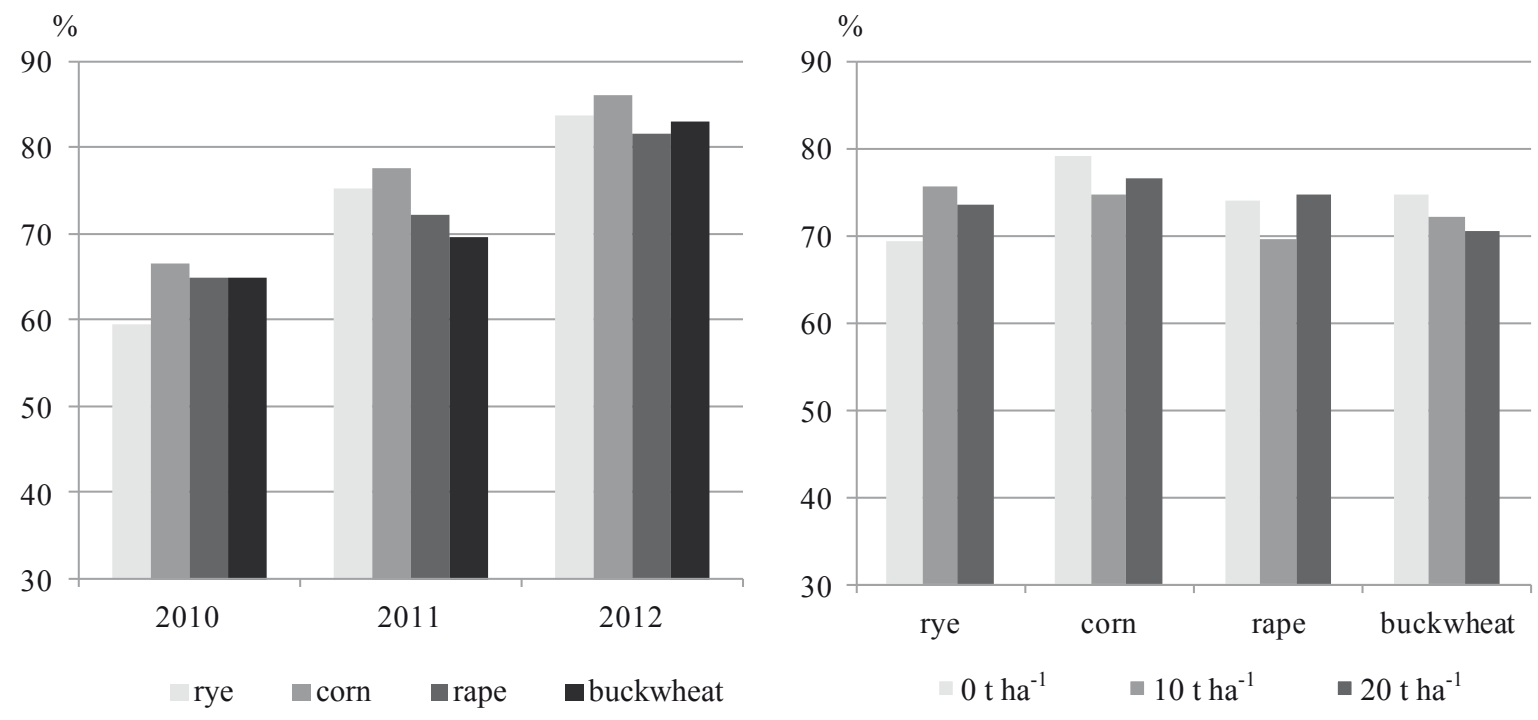

Figure 4. Share of marketable yield in the total yield of tomato (\%)

the development of fungal diseases on plants and fruits, which decreased the marketable yield. In broccoli cultivation the application of rye, corn and buckwheat straw, irrespective of dose, contributed to an increase in the share of the marketable yield of the total yield. A better effect was obtained in plots mulched with straw at a dose of 10 than 20 $\mathrm{t} \mathrm{ha}^{-1}$. An increase in the share of the marketable yield in plots mulched with straw at a dose of 10 t ha $\mathrm{a}^{-1}$ compared to the control amounted to $9.3 \%$ for rye straw, $7.2 \%$ for corn and $8.0 \%$ for buckwheat straw. Significant differences in plots mulched with rape straw were not found. However, soil mulching with rye straw increased the share of marketable yield in the total yield in tomato cultivation. In the case of rye straw, a dose of $10 \mathrm{t} \mathrm{ha}^{-1}$ increased the share of marketable yield to $6.4 \%$ and a dose of 20 $\mathrm{t} \mathrm{ha} \mathrm{h}^{-1}$ to $4.2 \%$. The application of corn and rape straw at a dose of $10 \mathrm{t} \mathrm{ha}^{-1}$ caused a decreased the share of marketable yield compared to the dose of $20 \mathrm{tha}^{-1}$ and non-mulched plots.

Table 3. Dry matter (\%) content in broccoli and tomato depending on kind of mulching straw in the years 2010-2012

\begin{tabular}{|c|c|c|c|c|c|c|c|}
\hline \multirow{2}{*}{ Species } & \multirow{2}{*}{\multicolumn{2}{|c|}{ Specification }} & \multicolumn{4}{|c|}{ Kind of straw } & \multirow{2}{*}{ Mean } \\
\hline & & & rye & corn & rape & buckwheat & \\
\hline \multirow{8}{*}{ Broccoli } & \multirow{3}{*}{ years } & 2010 & 8.25 & 8.54 & 8.03 & 8.52 & 8.34 \\
\hline & & 2011 & 7.36 & 7.63 & 6.86 & 7.30 & 7.29 \\
\hline & & 2012 & 11.06 & 11.04 & 10.31 & 9.67 & 10.52 \\
\hline & \multirow{3}{*}{$\begin{array}{l}\text { dose of straw } \\
\text { t ha }^{-1}\end{array}$} & No straw & 8.90 & 8.93 & 8.85 & 9.18 & 8.97 \\
\hline & & 10 & 8.69 & 9.03 & 7.69 & 7.81 & 8.31 \\
\hline & & 20 & 9.07 & 9.25 & 8.65 & 8.50 & 8.87 \\
\hline & \multicolumn{2}{|c|}{ mean } & 8.89 & 9.07 & 8.40 & 8.50 & 8.71 \\
\hline & \multicolumn{7}{|c|}{$\begin{array}{l}\mathrm{LSD}_{0.05} \text { for: years }=0.72 ; \text { kind of straw }=\text { n.s.; dose of straw }=\text { n.s.; years } \times \text { kind of straw }=\text { n.s.; kind of straw } \\
\times \text { dose of straw }=0.82\end{array}$} \\
\hline \multirow{8}{*}{ Tomato } & \multirow{3}{*}{ years } & 2010 & 6.21 & 6.40 & 6.14 & 6.36 & 6.28 \\
\hline & & 2011 & 7.09 & 7.17 & 7.12 & 7.29 & 7.17 \\
\hline & & 2012 & 6.51 & 6.42 & 6.30 & 6.26 & 6.37 \\
\hline & \multirow{3}{*}{$\begin{array}{l}\text { dose of straw } \\
\text { t ha }^{-1}\end{array}$} & No straw & 6.57 & 6.60 & 6.80 & 6.78 & 6.69 \\
\hline & & 10 & 6.68 & 6.71 & 6.47 & 6.65 & 6.63 \\
\hline & & 20 & 6.56 & 6.68 & 6.29 & 6.47 & 6.50 \\
\hline & \multicolumn{2}{|c|}{ mean } & 6.60 & 6.66 & 6.52 & 6.64 & 6.61 \\
\hline & \multicolumn{7}{|c|}{$\begin{array}{l}\mathrm{LSD}_{0.05} \text { for: years }=0.28 ; \text { kind of straw }=\text { n.s.; dose of straw }=0.17 ; \text { years } \times \text { kind of straw }=\text { n.s.; kind of straw } \\
\times \text { dose of straw }=0.20\end{array}$} \\
\hline
\end{tabular}


The content of dry matter in the broccoli amounted to $8.71 \%$ and ranged from $6.86 \%$ in broccoli from plots mulched with rape straw to $11.06 \%$ from plots mulched with rye straw (Tab. 3). A similar content of this component in broccoli was found by Wojciechowska et al. (2005) and Grabowska et al. (2009). The content of dry matter in tomato fruits amounted to $6.61 \%$. The most of this component $(7.29 \%)$ was found in fruits from plots with buckwheat straw and the least (6.14\%) was found in tomato cultivated on rape straw (Tab. 3). A similar content of dry matter in tomato fruits was found in the study by Majkowska-Gadomska et al. (2012).

Weather conditions in the years of the study significantly differentiated the content of dry matter in vegetables. The highest content of dry matter in broccoli and tomato was found in 2012 and 2011, respectively. These years were characterised by moderate rainfall compared to 2010 .

The study results showed a significant influence of the interaction between the kind and dose of straw application for soil mulching (Tab. 3). Changes in the dry matter content of broccoli were observed in plots mulched with rape and buckwheat straw. The rape and buckwheat straw at a dose of 10 t ha ${ }^{-1}$ caused a significant decrease in the content of dry matter compared to the control without straw. The differences amounted to 1.16 and $1.37 \%$, respectively. Soil mulched with rape and buckwheat straw also caused a significant decrease of dry matter content in tomato fruits compared to the control without mulch. The rye and corn straw did not have any influence on the dry matter content in the edible parts of the investigated species. In the study by Samaila et al. (2011a), soil mulching contributed to a significant increase in dry matter content in tomato fruits compared to the control without mulch. Similarly, the study by Najafabadi et al. (2012) showed that soil mulching with straw contributed to an increase of dry matter content in garlic bulbs. In the study by Olfati et al. (2008), organic mulch applied in carrot cultivation did not have any influence on the dry matter content in roots.

The content of ascorbic acid in broccoli ranged from $79.30 \mathrm{mg} 100 \mathrm{~g}^{-1}$ f.m. on the rye straw to 85.42 mg $100 \mathrm{~g}^{-1}$ f.m. on the buckwheat straw (Tab. 4). In the study by Yildirim et al. (2007), the content of vitamin $\mathrm{C}$ in broccoli ranged from 81 to $115 \mathrm{mg}$ $100 \mathrm{~g}^{-1} \mathrm{f}$.m. Slightly less content of this component, on average by $73 \mathrm{mg} 100 \mathrm{~g}^{-1}$ f.m., was found by Wojciechowska et al. (2005). The content of ascorbic acid in tomato fruits amounted on average

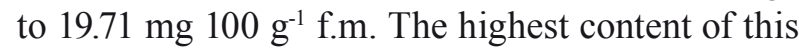
component (21.56 mg $100 \mathrm{~g}^{-1}$ f.m.) was found in fruits cultivated on corn straw (Tab. 4). A similar content of vitamin $\mathrm{C}$ in tomato fruits was shown

Table 4. Ascorbic acid (mg $100 \mathrm{~g}^{-1}$ f.m.) content in broccoli and tomato depending on kind of mulching straw in the years 2010-2012

\begin{tabular}{|c|c|c|c|c|c|c|c|}
\hline \multirow{2}{*}{ Species } & \multirow{2}{*}{\multicolumn{2}{|c|}{ Specification }} & \multicolumn{4}{|c|}{ Kind of straw } & \multirow{2}{*}{ Mean } \\
\hline & & & rye & corn & rape & buckwheat & \\
\hline \multirow{8}{*}{ Broccoli } & \multirow{3}{*}{ years } & 2010 & 81.62 & 83.63 & 83.36 & 83.97 & 83.15 \\
\hline & & 2011 & 81.32 & 85.37 & 83.82 & 85.42 & 83.98 \\
\hline & & 2012 & 82.08 & 81.77 & 82.81 & 82.59 & 82.31 \\
\hline & \multirow{3}{*}{$\begin{array}{l}\text { dose of straw } \\
\mathrm{t} \mathrm{ha}^{-1}\end{array}$} & No straw & 83.33 & 83.19 & 83.23 & 83.32 & 83.27 \\
\hline & & 10 & 79.30 & 83.04 & 83.88 & 85.11 & 82.83 \\
\hline & & 20 & 82.39 & 84.53 & 82.89 & 83.56 & 83.34 \\
\hline & \multicolumn{2}{|c|}{ mean } & 81.67 & 83.59 & 83.33 & 83.99 & 83.15 \\
\hline & \multicolumn{7}{|c|}{$\begin{array}{l}\mathrm{LSD}_{0.05} \text { for: years }=1.26 ; \text { kind of straw }=1.62 ; \text { dose of straw }=\text { n.s.; years } \times \text { kind of straw }=\text { n.s.; kind of straw } \\
\times \text { dose of straw }=2.08\end{array}$} \\
\hline \multirow{8}{*}{ Tomato } & \multirow{3}{*}{ years } & 2010 & 17.07 & 16.65 & 16.92 & 17.71 & 17.09 \\
\hline & & 2011 & 20.70 & 21.56 & 21.34 & 21.43 & 21.26 \\
\hline & & 2012 & 20.23 & 21.26 & 20.52 & 21.11 & 20.78 \\
\hline & \multirow{3}{*}{$\begin{array}{l}\text { dose of straw } \\
\text { t ha }^{-1}\end{array}$} & No straw & 20.43 & 19.28 & 20.07 & 19.79 & 19.89 \\
\hline & & 10 & 18.90 & 20.00 & 18.88 & 20.00 & 19.45 \\
\hline & & 20 & 18.68 & 20.18 & 19.83 & 20.46 & 19.79 \\
\hline & \multicolumn{2}{|c|}{ mean } & 19.34 & 19.82 & 19.60 & 20.09 & 19.71 \\
\hline & \multicolumn{7}{|c|}{$\begin{array}{l}\mathrm{LSD}_{0.05} \text { for: years }=0.83 ; \text { kind of straw }=\text { n.s.; dose of straw }=0.26 ; \text { years } \times \text { kind of straw }=\text { n.s.; kind of straw } \\
\times \text { dose of straw }=0.98\end{array}$} \\
\hline
\end{tabular}


Table 5. Total sugars (\% f.m.) content in broccoli and tomato depending on kind of mulching straw in the years 2010 2012

\begin{tabular}{|c|c|c|c|c|c|c|c|}
\hline \multirow{2}{*}{ Species } & \multirow{2}{*}{\multicolumn{2}{|c|}{ Specification }} & \multicolumn{4}{|c|}{ Kind of straw } & \multirow{2}{*}{ Mean } \\
\hline & & & rye & corn & rape & buckwheat & \\
\hline \multirow{8}{*}{ Broccoli } & \multirow{3}{*}{ years } & 2010 & 2.73 & 2.82 & 2.59 & 2.65 & 2.70 \\
\hline & & 2011 & 2.35 & 2.33 & 2.31 & 2.39 & 2.35 \\
\hline & & 2012 & 3.14 & 3.25 & 2.90 & 2.87 & 3.04 \\
\hline & \multirow{3}{*}{$\begin{array}{c}\text { dose of straw } \\
\mathrm{t} \mathrm{ha}^{-1}\end{array}$} & No straw & 2.71 & 2.68 & 2.65 & 2.74 & 2.70 \\
\hline & & 10 & 2.65 & 2.89 & 2.66 & 2.57 & 2.69 \\
\hline & & 20 & 2.86 & 2.83 & 2.48 & 2.60 & 2.69 \\
\hline & \multicolumn{2}{|c|}{ mean } & 2.74 & 2.80 & 2.60 & 2.64 & 2.69 \\
\hline & \multicolumn{7}{|c|}{$\begin{array}{l}\mathrm{LSD}_{0.05} \text { for: years }=0.14 ; \text { kind of straw }=0.17 \text {; dose of straw }=\text { n.s.; years } \times \text { kind of straw }=\text { n.s.; kind of straw } \\
\times \text { dose of straw }=0.18\end{array}$} \\
\hline \multirow{8}{*}{ Tomato } & \multirow{3}{*}{ years } & 2010 & 2.49 & 2.63 & 2.61 & 2.85 & 2.64 \\
\hline & & 2011 & 2.76 & 2.74 & 2.71 & 2.79 & 2.75 \\
\hline & & 2012 & 2.65 & 2.49 & 2.61 & 2.50 & 2.56 \\
\hline & \multirow{3}{*}{$\begin{array}{c}\text { dose of straw } \\
\mathrm{t} \mathrm{ha}^{-1}\end{array}$} & No straw & 2.63 & 2.52 & 2.55 & 2.69 & 2.60 \\
\hline & & 10 & 2.58 & 2.68 & 2.71 & 2.75 & 2.68 \\
\hline & & 20 & 2.69 & 2.66 & 2.67 & 2.70 & 2.68 \\
\hline & \multicolumn{2}{|c|}{ mean } & 2.63 & 2.62 & 2.64 & 2.71 & 2.65 \\
\hline & \multicolumn{7}{|c|}{$\begin{array}{l}\mathrm{LSD}_{0.05} \text { for: years }=0.15 ; \text { kind of straw }=\text { n.s.; dose of straw }=0.08 ; \text { years } \times \text { kind of straw }=\text { n.s.; kind of straw } \\
\times \text { dose of straw }=0.10\end{array}$} \\
\hline
\end{tabular}

in the study by Dzida and Jarosz (2005). A higher content of ascorbic acid, on average by $30.0 \mathrm{mg} 100$ $\mathrm{g}^{-1}$ f.m., was found by Majkowska-Gadomska et al. (2012).

The highest content of ascorbic acid both in broccoli heads and tomato fruits was found in 2011, which was characterised by the lowest rainfall at the end of the plant growing period.

On the basis of the obtained results, A significant influence of the kind and dose of straw applied to soil mulching on the content of ascorbic acid in the vegetables was found (Tab. 4). The application of rye straw at a dose of $10 \mathrm{tha}^{-1}$ caused a significant decrease of ascorbic acid in broccoli. Soil mulching with rye straw also contributed to decreased ascorbic acid content in tomato fruits compared to the control without straw. Fruits from plots with rape straw at a dose of $10 \mathrm{tha}^{-1}$ showed a significantly lower content of this component compared to the control plot. A lower content of ascorbic acid in the edible parts of the investigated species on the rye and rape straw compared to the remaining kinds of straw could be caused by the size of the fruits. The concentration of nutrients is lower in large fruits. In the study by Najafabadi et al. (2012), soil mulching with straw contributed to increased vitamin $\mathrm{C}$ content in garlic bulbs. On the contrary, Sekhon et al. (2008) found significantly higher content of ascorbic acid in sweet pepper fruits cultivated in a control plot without mulch, compared to the plots with organic mulch. Gajc-Wolska et al. (2005) found that sweet pepper fruits cultivated on mulch with straw contained significantly more vitamin C compared to those cultivated on polypropylene fibre mulch.

The lower content of dry matter and ascorbic acid in broccoli and tomato in the plots mulched with rape, buckwheat and rye straw could be also a result of higher soil moisture under mulch.

The content of total sugars, irrespective of the kinds and dose of straw, amounted to $2.69 \%$ f.m. in broccoli and $2.65 \%$ f.m. in tomato fruits (Tab. 5 ). The content of total sugars in tomatoes in the study by Dzida and Jarosz (2005) was on a similar level ( $2.52 \%$ f.m. on average). More total sugars in tomato fruits $(3.50 \%$ f.m. on average) were found by Majkowska-Gadomska et al. (2012).

The effects of weather conditions in the years of the study on the total sugar content were the same as on the dry matter. The highest total sugars were found in 2012 in broccoli and in 2011 in tomato. An interaction of the kinds and dose of straw had a significant influence on the total sugar content in both vegetable species (Tab. 5). The rye straw at a dose of $20 \mathrm{tha}^{-1}$ contributed to better accumulation of total sugars in broccoli and tomato compared to the dose of $10 \mathrm{t} \mathrm{ha}^{-1}$. Irrespective of dose, tomato cultivated on the corn and rape straw accumulated 
Table 6. Monosaccharides (\% f.m.) content in broccoli and tomato depending on kind of mulching straw in the years 2010-2012

\begin{tabular}{|c|c|c|c|c|c|c|c|}
\hline \multirow{2}{*}{ Species } & \multirow{2}{*}{\multicolumn{2}{|c|}{ Specification }} & \multicolumn{4}{|c|}{ Kind of straw } & \multirow{2}{*}{ Mean } \\
\hline & & & rye & corn & rape & buckwheat & \\
\hline \multirow{8}{*}{ Broccoli } & \multirow{3}{*}{ years } & 2010 & 1.53 & 1.56 & 1.56 & 1.57 & 1.56 \\
\hline & & 2011 & 1.55 & 1.56 & 1.55 & 1.57 & 1.56 \\
\hline & & 2012 & 1.51 & 1.56 & 1.56 & 1.59 & 1.56 \\
\hline & \multirow{3}{*}{$\begin{array}{c}\text { dose of straw } \\
\text { t ha }^{-1}\end{array}$} & No straw & 1.53 & 1.54 & 1.54 & 1.52 & 1.53 \\
\hline & & 10 & 1.54 & 1.58 & 1.59 & 1.61 & 1.58 \\
\hline & & 20 & 1.53 & 1.55 & 1.54 & 1.58 & 1.55 \\
\hline & \multicolumn{2}{|c|}{ mean } & 1.53 & 1.56 & 1.56 & 1.57 & 1.56 \\
\hline & \multicolumn{7}{|c|}{$\begin{array}{l}\text { LSD }_{0.05} \text { for: years }=\text { n.s.; kind of straw }=0.03 ; \text { dose of straw }=0.03 ; \text { years } \times \text { kind of straw }=\text { n.s.; kind of straw } \\
\times \text { dose of straw }=0.03\end{array}$} \\
\hline \multirow{8}{*}{ Tomato } & \multirow{3}{*}{ years } & 2010 & 1.03 & 1.01 & 1.08 & 0.95 & 1.02 \\
\hline & & 2011 & 1.01 & 0.97 & 0.94 & 1.00 & 0.98 \\
\hline & & 2012 & 0.98 & 0.97 & 1.02 & 0.98 & 0.99 \\
\hline & \multirow{3}{*}{$\begin{array}{c}\text { dose of straw } \\
\mathrm{t} \mathrm{ha}^{-1}\end{array}$} & No straw & 1.00 & 0.95 & 0.98 & 0.97 & 0.97 \\
\hline & & 10 & 1.01 & 1.00 & 1.02 & 0.97 & 1.00 \\
\hline & & 20 & 1.01 & 1.00 & 1.03 & 0.99 & 1.01 \\
\hline & \multicolumn{2}{|c|}{ mean } & 1.00 & 0.98 & 1.01 & 0.98 & 0.99 \\
\hline & \multicolumn{7}{|c|}{$\begin{array}{l}\mathrm{LSD}_{0.05} \text { for: years }=0.03 ; \text { kind of straw }=\text { n.s.; dose of straw }=0.02 ; \text { years } \times \text { kind of straw }=0.07 \text {; kind of straw } \\
\times \text { dose of straw }=0.02\end{array}$} \\
\hline
\end{tabular}

more total sugars compared to the control. However, corn and rape straw at a dose of $10 \mathrm{tha}^{-1}$ was more favourable for the accumulation of this compound in broccoli. Cultivation on the buckwheat straw did not cause changes in the content this component in the investigated vegetables. In the study by Samaila et al. (2011a), soil mulching caused a significant increase of carbohydrates in tomato fruits compared to the control without mulch.

The content of monosaccharides in broccoli amounted to $1.56 \%$ f.m. on average from the three study years and $0.99 \%$ f.m. in tomato fruits (Tab. 6). In the study by Grabowska et al. (2009), the content of this component in broccoli amounted to
0.54 to $1.53 \%$ f.m. The content of monosaccharides in tomato in the study by Adamczewska-Sowińska and Kołota (2008) was higher and amounted to $3.28 \%$ on average.

Weather conditions in the years of study had no influence on the monosaccharide content in broccoli; however, a higher content of this component in tomato fruits was found in 2010 in plots mulched with rape straw.

The obtained results indicate a significant effect an the interaction of the investigated factors on the monosaccharide content in vegetables. The highest content of monosaccharides in broccoli from the plots with corn, rape and buckwheat straw at a dose

Table 7. Flesh acidity of tomato (g $100 \mathrm{~g}^{-1}$ counted on lemon acid) depending on kind of mulching straw in the years 2010-2012

\begin{tabular}{|c|c|c|c|c|c|c|}
\hline \multirow{2}{*}{ Specification } & & \multicolumn{4}{|c|}{ Kind of straw } & \multirow{2}{*}{ Mean } \\
\hline & & rye & corn & rape & buckwheat & \\
\hline \multirow{3}{*}{ Years } & 2010 & 0.37 & 0.37 & 0.37 & 0.38 & 0.37 \\
\hline & 2011 & 0.45 & 0.46 & 0.46 & 0.45 & 0.46 \\
\hline & 2012 & 0.41 & 0.42 & 0.41 & 0.41 & 0.41 \\
\hline \multirow{3}{*}{$\begin{array}{l}\text { Dose of straw } \\
\mathrm{t} \mathrm{ha}^{-1}\end{array}$} & No straw & 0.42 & 0.41 & 0.42 & 0.41 & 0.42 \\
\hline & 10 & 0.40 & 0.42 & 0.40 & 0.42 & 0.41 \\
\hline & 20 & 0.40 & 0.42 & 0.42 & 0.42 & 0.42 \\
\hline Mean & & 0.41 & 0.42 & 0.41 & 0.42 & 0.41 \\
\hline
\end{tabular}


of $10 \mathrm{tha}^{-1}$ was found. Irrespective of dose, the corn and rape straw increased monosaccharide content in tomato fruits.

The average flesh acidity of tomato in the study

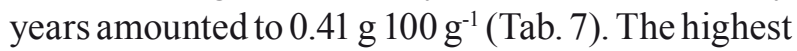
flesh acidity was found in fruits in 2011. The kind of straw and its dosage had a significant influence on flesh acidity. The study results indicated significantly decreased flesh acidity as a result of rye straw application. Also, rape straw at a dose of $10 \mathrm{tha}^{-1}$ decreased flesh acidity. The application of corn and buckwheat straw to soil mulching did not cause changes in flesh acidity. Similarly to ascorbic acids, the decreased flesh acidity of fruits cultivated on rye straw could be caused by decreasing nutrient accumulation because of the heavy weight of the fruits.

In the study by Gajc-Wolska et al. (2005), sweet pepper fruits cultivated on organic mulch obtained higher notes of fresh smell, fragility and flesh succulence; those cultivated on polypropylene fibre had harder peels and a more sour taste. An analysis of the chemical composition of tomatoes in the study by Adamczewska-Sowińska and Kołota (2008) did not indicate significant differences in the content of dry matter, vitamin $\mathrm{C}$, total sugars and monosaccharides after living mulches were applied. In a later study regarding eggplant cultivation, the authors (Adamczewska-Sowińska and Kołota 2010) found increased dry matter content in fruits from plants cultivated on living mulch $(9.40 \%)$ compared to black foil (7.48\%). However, the kind of mulch had no influence on the vitamin $\mathrm{C}$ content in the eggplant fruits.

\section{CONCLUSION}

1. Weather conditions in the years of the study had a higher degree of influence on the vegetable yield and accumulation of nutritive compounds. The highest broccoli yield was achieved in 2010, which was characterised by higher rainfall, and tomato in 2011. The highest contents of the investigated compounds in broccoli heads and tomato fruits were found in moderate moisture in 2011 and 2012.

2. All straws irrespective of dosage contributed to a significant increase in the yield of broccoli compared to the control without straw. In tomato cultivation better yielding effect was obtained in plots mulched with straw at a dose of $10 \mathrm{tha}^{-1}$.

3. Soil mulching with rape and buckwheat straw decreased the content of dry matter in broccoli and tomato. The application of mulch with rape straw also caused a reduction in the content of ascorbic acid in tomato fruits. In turn, mulch with rye straw decreased ascorbic acid in the edible parts of the investigated species and a reduction of the flesh acidity of tomato.

4. The application of corn and rape straw at a dose of $10 \mathrm{tha}^{-1}$ contributed to increase the content of total sugars and monosaccharaides in broccoli. These straws, irrespective of dosage also caused an increase in the content of sugars in tomato fruits.

\section{ACKNOWLEDGEMENTS}

This research is supported by the Ministry of Science and Higher Education of Poland as part of the statutory activities of the Department of Vegetable Crops, Siedlce University of Natural Sciences and Humanities.

\section{REFERENCES}

Adamczewska-Sowińska K., KoŁota E., 2008. The effect of living mulches on yield and quality of tomato fruits. Veg. Crops Res. Bull. 69: 31-38.

AdamcZewsKa-SowiŃSKa K., KoŁota E., 2010. Yielding and nutritive value of field cultivated eggplant with the use of living and synthetic mulches. Acta Sci. Pol., Hortorum Cultus 9(3): 191-199.

Birch C. J., Rickert K.G., Wearing A.H., Tan D.K.Y., 2000. Broccoli yield and quality can be determined by cultivar and temperature but not photoperiod in south - east Queensland. Aust. J. Exp. Agric. 39: 901-909.

BuöRkMAn T., Pearson J., 1998. High temperature arrest of inflorescence development in broccoli (Brassica oleracea var. italica L.). J. Exp. Bot. 49: 101-106.

Borowy A., 2012. Growth and yield of stake tomato under no-tillage cultivation using hairy vetch as a living mulch. Acta Sci. Pol., Hortorum Cultus 11(2): 229-252.

Dahiya R., Ingwersen J., Streck T., 2007. The effect of mulching and tillage on the water and temperature regimes of a loess soil: experimental findings and modeling. Soil Tillage Res. 96: 52-63.

Dzida K., Jarosz Z., 2005. Effect of different levels of nitrogen fertilization and additional foliage feeding on the yield and some elements in leaves and fruits of tomato. Ann. UMCS, Sect. EEE, XV: 51-58.

Gajc-Wolska J., Zielony T., Radzanowska T., 2005. Evaluation of yield and fruit quality of new hybrids of sweet pepper (Capsicum annuum L.). Zesz. Nauk. AR we Wrocławiu 515, Rolnictwo 86: 139-147.

Ghosh P.K., Dayal D., Bandyopadhyay K.K., Mohanty M., 2006. Evaluation of straw and polythene mulch 
for enhancing productivity of irrigated summer groundnut. Field Crops Res. 99: 76-86.

Grabowska A., Kunicki E., Libik A., 2009. The effects of different methods of cultivation and plant spacing on the chemical composition of broccoli heads. Folia Hort. 21(2): 25-34.

Grassbaugh E.M., Regnier E.E., Bennett M.A., 2004. Comparison of organic and inorganic mulches for heirloom tomato production. Acta Hort. 638: 171176.

KaŁuŻewicz A., Krzesiński W., Knaflewski M., Lisiecka J., Spiżewski T., Frąszczak B., 2010. The effect of temperature on the broccoli yield and length of the period from head initiation to harvest. Acta Sci. Pol., Hortorum Cultus 9(3): 167-174.

Karistsapol N., Quanchitb S., Sompongb T., 2013. Effect of planting date and variety on growth and yield of broccoli during the dry season in southern Thailand. IJPAES 3(2): 121-124.

LeE S.K., Kadar A.A., 2000. Preharvest and postharvest factors influencing vitamin $\mathrm{C}$ content of horticultural crops. Postharvest Biol. Technol. 20: 207-220.

MajkowsKa-Gadomska J., Wierzbicka B., ArcichowsKa K., 2012. Yield and quality of tomato (Lycopersicon esculentum Mill.) fruit harvested from plants grown in mulched soil. Acta Agrobot. 65(4): 149-156.

Najafabadi Mahdieh M.B., Peyvast Gh., Hassanpour Asil M., Olfati J.A., Rabiee M., 2012. Mulching effects on the yield and quality of garlic as second crop in rice fields. Int. J. Plant Prod. 6(3): 279-290.

Olfati J.A., Peyvast Gh., Nosrati-Rad Z., 2008. Organic mulching on carrot yield and quality. Int. J. Veg. Sci. 14(4): 362-368.

PN-A-04019, 1998. Determine of vitamin C content using the Tillman method.

PN-90/A-75101/03, 1990. Determine the content of dry matter using the weight method.

PN-90/A-75101/07, 1990. Determine the content of total sugars as well as saccharose and monosaccharides using the Luff-Schoorl method.

Rahman M.J., Uddin M.S., Bagum S.A., Mondol A.T.M.A.I., Zaman M.M., 2006. Effect of mulches on the growth and yield of tomato in the costal area of Bangladesh under rainfed condition. Int. J. Sustain. Crop. Prod. 1: 6-10.

SAdY W., 2000. Fertilization of field vegetables. Plantpress, Kraków.

Saeed R., Ahmad R., 2009. Vegetative growth and yield of tomato as affected by the application of organic mulch and gypsum under saline rhizosphere. Pak. J. Bot. 41(6): 3093-3105.

Samaila A.A., Amans E.B., Abubakar I.U., Babaji B.A., 2011a. Nutritional quality of tomato (Lycopersicon esculentum Mill) as influenced by mulching, nitrogen and irrigation interval. J. Agric. Sci. 3(1): 266-270.

Samaila A.A., Amans E.B., Babaji B.A., 2011b. Yield and fruit quality of tomato (Lycopersicon esculentum
Mill) as influenced by mulching, nitrogen and irrigation interval. Int. Res. J. Agric. Sci. Soil Sci. 1(3): 90-95.

Schonbeck, M.W., Evalylo G.E., 1998. Effects of mulches on soil properties and tomato production. I. Soil temperature, soil moisture, and marketable yield. J. Sustain. Agric. 13: 55-81.

Sekhon N.K., Singh Ch.B., Sidhu A.S., Thind S.S., Hira G.S., Khurana D.S., 2008. Effect of straw mulching, irrigation and fertilizer nitrogen levels on soil hydrothermal regime, water use and yield of hybrid chilli. Arch. Agron. Soil Sci. 54(2): 163-174.

SinkevičIenė A., Jodaugienė D., Pupalienè R., Urbonienė M., 2009. The influence of organic mulches on soil properties and crop yield. Agron. Res. 7(1): 485-491.

Steinmetz K.A., Potter J.D., 1996. Vegetables, fruit and cancer prevention: a review. J. Am. Diet. Assoc. 96: 1027-1039.

Thakur P.S., Thakur A., Kanaujia S.P., 2000. Reversal of water stress effects. I. Mulching impact on the performance of Capsicum annuum under water deficit. Indian J. Hort. 57(3): 250-254.

Wojciechowska R., Rożek S., Rydz A., 2005. Broccoli yield and its quality in spring growing cycle as dependent on nitrogen fertilization. Folia Hort. 17(2): 141-152.

WRB FAO, 1998. World Reference Base for Soil Resources, World Soil Resource Reports FAO, ISRIC, ISSS, Rome.

Yildirim E., Guvenc I., Turan M., Karatas A., 2007. Effect of foliar urea application on quality, growth, mineral uptake and yield of broccoli (Brassica oleracea L., var. italica). Plant Soil Environ. 53(3): 120-128.

\section{WPŁYW MULCZOWANIA GLEBY SŁOMA NA PLON I ZAWARTOŚĆ WYBRANYCH SKŁADNIKÓW WARTOŚCI ODŻYWCZEJ W RÓŻACH BROKUŁU I OWOCACH POMIDORA}

Streszczenie: Mulcze poprzez utrzymanie właściwej wilgotności oraz zmniejszenie dobowych wahań temperatury gleby poprawiają warunki wzrostu i rozwoju roślin, a w rezultacie korzystnie wpływają na plonowanie warzyw. Skład chemiczny warzyw jest uwarunkowany genetycznie, jak również kształtowany jest poprzez czynniki oddziaływujące na roślinę w czasie wzrostu, a przede wszystkim warunki klimatyczne i zabiegi agrotechniczne. W doświadczeniu badano wpływ ściółkowania gleby słomą żytnią, kukurydzianą, rzepakową i gryczaną w dawce 10 i 20 t ha $^{-1}$ na wielkość plonu oraz zmiany zawartości wybranych składników odżywczych w różach brokułu 'Milady' $\mathrm{F}_{1}$ i owocach pomidora 'Polfast' $F_{1}$. Efekty działania mulczu ze słomy porównano z obiektem kontrolnym bez ściółkowania. Plon warzyw oraz ich skład chemiczny w dużym stopniu zależały od warunków pogodowych w latach badań. 
Najbardziej korzystny dla plonowania brokułu okazał się rok 2010, a dla pomidora 2011. Więcej składników odżywczych w różach i owocach stwierdzono w latach 2011 i 2012, charakteryzujących się korzystnym rozkładem opadów. Wszystkie stosowane w badaniach słomy, niezależnie od dawki powodowały wzrost plonu brokułu. Natomiast lepsze dla plonowania pomidora okazało się stosowanie mulczu ze słomy w dawce 10 tha $^{-1}$. Mulczowanie słomą żytnią, kukurydzianą i gryczaną zwiększało udział plonu handlowego w plonie ogółem brokułu, a słomą żytnią także udział plonu handlowego pomidora. Mulczowanie gleby słomą rzepakową i gryczaną obniżało zawartość suchej masy w częściach jadanych warzyw. Mulcz ze słomy żytniej przyczynił się do obniżenia zawartości kwasu askorbinowego w różach i owocach, a także nieznacznie obniżał kwasowość miąższu pomidora. Natomiast mulczowanie słomą kukurydzianą i gryczaną spowodowało zwiększenie zawartości cukrów ogółem i redukujących w różach brokułu i owocach pomidora.

Received November 6, 2013; accepted February 22, 2014 